\title{
HUBUNGAN ANTARA LAMA MENJALANI HEMODIALISIS DENGAN KUALITAS HIDUP PASIEN GAGAL GINJAL KRONIK DI RS GATOEL MOJOKERTO
}

\author{
Heni Purwati*, Sri Wahyuni LS** \\ STIKes Bina Sehat PPNI Kabupaten Mojokerto
}

\begin{abstract}
ABSTRAK
Terapi Hemodialisis pada pasien gagal ginjal kronik dapat merubah kondisi fisik, psikologi, sosial dan ekonomi pasien karena harus dijalani seumur hidupnya. Hal ini dapat mempengaruhi kualitas hidup pasien sehingga lama menjalani hemodialisis merupakan salah satu faktor yang mempengaruhi kualitas hidup pasien gagal ginjal kronik. Kualitas hidup merupakan penilaian yang terfokus pada penerimaan individu terhadap kondisiya. Setiap individu membutuhkan waktu yang berbeda-beda untuk menerima segala kondisinya. Tujuan dari penelitian adalah untuk mengetahui Hubungan antara Lama Menjalani Hemodialisis dengan Kualitas Hidup Pasien Gagal Ginjal Kronik di RS Gatoel Mojokerto. Penelitian ini menggunakan metode cross sectional design. Populasinya adalah pasien gagal ginjal kronik yang menjalani hemodialisis sebanyak 150 orang. Sampel penelitian ini diambil menggunakan teknik nonprobability sampling dengan tipe purposive sampling sebanyak 103 orang. Data diperoleh dari kuesioner KDQoL 36. Hasil penelitian menggunakan uji spearman rho dengan bantuan SPSS V.16 menunjukan $p<\alpha(0,006<0,05)$. Artinya $\mathrm{H}_{0}$ ditolak sehingga, Ada Hubungan antara Lama Menjalani Hemodialisis dengan Kualitas Hidup Pasien Gagal Ginjal kronik di RS Gatoel Mojokerto. Kualitas hidup pasien mengalami fluktuasi berdasarkan tahapan adaptasi terhadap hemodialisis dan penyakit. Namun sebagian besar pasien menjalani hemodialisis lebih dari 12 bulan memiliki kualitas hidup yang cukup karena pasien sudah terbiasa dengan terapi beserta gejala dan komplikasi yang dirasakanya. Tetapi ada faktor lain yang mempengaruhi kualitas hidup seperti jenis kelamin, status pernikahan dan tingkat pendidikan. Pasien juga diharapkan mematuhi anjuran dan larangan yang diberikan guna meningkatkan kualitas hidup pasien.
\end{abstract}

\section{Kata Kunci: Gagal Ginjal Kronik, Hemodialisis, Kualitas Hidup}

\begin{abstract}
Hemodialysis therapy of patients with chronic kidney desease can changes the patients physically, psychological, social and economics because they have to deal with it for the rest of their life. This can affect the quality of life of the patients because of the long term of hemodialis therapy, this is one of factors that affect the quality of life of the patients with chronic kidney disease. Quality of life is focused on the assessment of the individual against conditions acceptance. Each individual takes different phases to accept the condition. The purposes of the study was to determine of the relationship between the duration of hemodialysis and quality of life of the patients with chronic kidney disease at Gatoel Hospital Mojokerto. This research used cross sectional design. The patients population with chronic kidney disease undergoing on hemodialis is 150 people. The research sample is drawn using sampling techniques with the type of nonprobabillity purposive sampling with 130 people as sample. Data obtained from questionnares KDQoL 36. The result using Spearman rho test using SPSS V.16 shows $p<\alpha(0,006<0,05)$. HO rejected, this mean that there is relationship between the duration of hemodialysis and quality of life with chronic kidney disease at Gatoel Hospital Mojokerto. The quality of life of the patients fluctuated based on the stage adaptation of the hemodialysis and disease. However, most patients with the duration of hemodialysis for more than 12 month had a sufficient quality of life and their therapy are already familiar with the symptoms and complications, but there are other factors that affect quality of life such as gender, marital status and education level. Patients are also expected to cooperate in what to do and not to do to improve the quality of life of the patients.
\end{abstract}

Keywords: Chronic kidney disease, Hemodialysis, Quality of Life 


\section{Pendahuluan}

Gagal ginjal kronik merupakan gangguan fungsi ginjal yang progresif dan irreversible, sehingga penderita gagal ginjal kronik akan kehilangan fungsi ginjal secara bertahap dan tidak dapat ubah. Penderita gagal ginjal kronik (GGK) memerlukan terapi yang bertujuan untuk menunjang kehidupanya yaitu terapi hemodialisis (HD) atau cangkok ginjal. Bagi pasien gagal ginjal kronik, terapi hemodialisis harus dilakukan seumur hidupnya (Muhammad, 2012).

Terapi HD dapat memperpanjang usia tanpa batas yang jelas, namun tindakan ini tidak akan mengubah perjalanan alami penyakit ginjal yang mendasari, dan juga tidak akan mengembalikan seluruh fungsi ginjal. Pasien tetap akan mengalami sejumlah permasalah dan komplikasi dari penyakitnya (Brunner \& Suddarth, 2002). Terapi HD juga akan mempengaruhi keadaan psikologis, sosial dan ekonomi pasien. Pasien akan mengalami gangguan proses berpikir serta gangguan dalam berhubungan sosial. Belum lagi masalah kehilangan pekerjaan, perubahan peran di keluarga, perubahan hubungan dan waktu yang terbuang untuk dialisis serta biaya yang dikeluarkan untuk rutin menjalani hemodialisis. Semua kondisi tersebut akan menyebabkan menurunnya kualitas hidup pasien GGK yang menjalani terapi HD (Mailani, 2015).

Indonesia termasuk Negara dengan tingkat penderita penyakit ginjal kronik yang cukup tinggi, data dari ASKES tahun 2010 tercatat 17.507 pasien, tahun berikutnya tercatat 23.261 dan data terakhir tahun 2013 tercatat 24.141 orang pasien (Mailani, 2015). Sedangkan berdasarkan dari Riset Kesehatan Dasar (Riskesdas) tahun 2013 di dapatkan bahwa prevalensi dan insiden gagal ginjal kronik di Indonesia sekitar $0,2 \%$ sedangkan pada Provinsi Jawa Timur prevalensi dan insiden gagal ginjal kronik 0,3\%.

Menurut Indonesian Renal Registry (IRR) pasien baru yang menjalani hemodialisis mengalami peningkatan dari tahun 2011 ke 2012 yakni dari 15.353 jiwa menjadi 19.621 jiwa. Dari 19.621 jiwa pasien baru yang aktif melakukan hemodialisis hanya 9.161 jiwa yang didominasi oleh pria yakni 5.602 jiwa dan perempuan 3.559 jiwa. Untuk total pasien baru dan lama yang menjalani hemodialisis rutin di Indonesia sebanyak 717.497 jiwa sedangkan di Jawa
Timur sendiri yang menjalani Hemodialisis rutin 97.522 jiwa.

Mengacu dari penelitian Sofiana Nurchayati (2011) analisis faktor-faktor yang berhubungan dengan kualitas hidup pasien penyakit ginjal kronik yang menjalani hemodialisis di Rumah Sakit Islam Fatimah Cilacap dan Rumah Sakit Umum Daerah Banyumas menyatakan bahwa ada hubungan antara lama HD (Hemodialisis) dengan kualitas hidup, dengan hasil $(\mathrm{p}=0,035)$, $\mathrm{OR}=2,637$ yang artinya responden yang belum lama menjalani $H D \leq 11$ bulan berisiko 2,6 kali hidupnya kurang berkualitas.

Berdasarkan Hasil Studi

Pendahuluan pada tanggal 25 Februari 2016 di ruang hemodialisis RS Gatoel Mojokerto didapatkan jumlah pasien regular yang menjalani hemodialisis di RS Gatoel berjumlah 150 pasien. Setelah dilakukan wawancara 7 dari 10 pasien sudah menjalani hemodialisis lebih dari 11 bulan, mereka mengatakan sudah menerima semua keadaan yang terjadi pada dirinya karena sudah terbiasa menjalani hemodialisis beserta gejala dan komplikasi dari hemodialisis, mereka mengatakan tetap patuh menjalani hemodialisis untuk mempertahankan hidupnya. Pada 3 pasien yang menjalani hemodialisis kurang dari 11 bulan, mereka mengatakan merasa hidupnya lebih dibatasi dari sebelumnya, banyak aturan yang harus mereka jalani dan harus rutin ke rumah sakit untuk menjalani hemodialisis seumur hidup.

Faktor yang mempengaruhi kualitas hidup pada pasien yang menjalani hemodialisis antara lain faktor demografi seperti umur, jenis kelamin, pendidikan, dan pekerjaan serta faktor lain yaitu lama menjalani hemodialisis dan status fungsional kesehatanya (Satvik et al 2008; Nurchayati 2011). Kualitas hidup merupakan penilaian dan kepuasan klien terhadap tingkat dan fungsi kehidupan mereka dibandingkan dengan keadaan ideal yang seharusnya bisa dicapai menurut klien (Farida, 2010).

Pasien yang mejalani terapi hemodialisis kurang dari 12 bulan memiliki kualitas hidup yang lebih buruk dari pada pasien yang menjalani terapi sudah lebih dari sama dengan 12 bulan. Hal ini disebabkan pasien baru masih mencoba beradaptasi dengan kondisi yang dialaminya. Semakin lama pasien menjalani hemodialisis maka pasien akan semakin patuh untuk menjalani 
hemodialisis, karena mereka telah mencapai tahap menerima dan kemungkinan banyak mendapatkan pendidikan kesehatan dari perawat serta dokter tentang pemyakit dan juga pentingnya melaksanakan hemodialisis secara teratur bagi mereka (Bestari, 2015).

Berdasarkan latar belakang tersebut, maka peneliti tertarik untuk mengangkat masalah hubungan antara lama menjalani hemodialisis dengan kualitas hidup pasien gagal ginjal kronik di RS Gatoel Mojokerto.

\section{Metode}

Penelitian ini menggunakan desain penelitian Cross sectional yaitu jenis penelitian yang menekankan waktu pengukuran/ observasi data variabel dependen dan independen hanya satu kali waktu pada satu saat (Nursalam, 2013). Populasinya adalah pasien gagal ginjal kronik yang menjalani hemodialisis sebanyak 150 orang. Sampel penelitian ini diambil menggunakan teknik nonprobability sampling dengan tipe purposive sampling sebanyak 103 orang. Dengan kriteria sampel dalam penelitian ini terdiri dari :

1. Kriteria Inklusi

a. Pasien yang bersedia mengikuti penelitian dan menandatangani informed consent.

2. Kriteria Eksklusi

a. Pasien yang menjalani HD $<3$ bulan.

b. Pasien berusia di bawah 18 tahun.

Hasil

Tabel 1. Distribusi Frekuensi Responden Berdasarkan Jenis Kelamin.

\begin{tabular}{lllc}
\hline No & $\begin{array}{l}\text { Jenis } \\
\text { Kelamin }\end{array}$ & (f) & $\begin{array}{c}\text { Prosentas } \\
\%)\end{array}$ \\
\hline 1. & Laki-laki & 54 & 52,4 \\
2. & Perempuan & 49 & 47,6 \\
\hline Jumlah & 103 & 100 \\
\hline
\end{tabular}

Sumber: Data tahun 2016

Tabel di atas menunjukan bahwa sebagian besar responden berjenis kelamin laki-laki sebanyak 54 orang $(52,4 \%)$.
Tabel 2. Distribusi Frekuensi Responden Berdasarkan Usia

\begin{tabular}{|c|c|c|c|}
\hline No. & Usia & (f) & $\begin{array}{l}\text { Prosentase } \\
(\%)\end{array}$ \\
\hline 1. & $17-25$ th & 1 & 1 \\
\hline 2. & $26-35$ th & 9 & 8,7 \\
\hline 3. & $36-45$ th & 24 & 23,3 \\
\hline 4. & $46-55$ th & 41 & 39,8 \\
\hline 5. & $56-65$ th & 25 & 24,3 \\
\hline 6. & $>65$ th & 3 & 2,9 \\
\hline \multicolumn{2}{|c|}{ Jumlah } & 103 & 100 \\
\hline
\end{tabular}

Sumber: Data tahun 2016

Tabel di atas menunjukan bahwa hampir setengah responden berusia 46-55 tahun sebanyak 41 orang $(39,8 \%)$.

Tabel 3. Distribusi Frekuensi Responden Berdasarkan Status Pekerjaan

\begin{tabular}{clcl}
\hline No. & $\begin{array}{l}\text { Status } \\
\text { Pekerjaan }\end{array}$ & (f) & $\begin{array}{l}\text { Prosentase } \\
(\%)\end{array}$ \\
\hline 1. & Bekerja & 29 & 28,2 \\
2. & Tidak & 74 & 71,8 \\
& Bekerja & & \\
\hline \multicolumn{2}{l}{ Jumlah } & 103 & 100 \\
\multicolumn{2}{l}{ Sumber: Data tahun 2016}
\end{tabular}

Tabel di atas menunjukan bahwa sebagian besar responden sudah tidak bekerja sebanyak 74 orang $(71,8 \%)$.

Tabel 4. Distribusi Frekuensi Responden Berdasarkan Status Pernikahan

\begin{tabular}{llll}
\hline No. & $\begin{array}{l}\text { Status } \\
\text { Pernikahan }\end{array}$ & (f) & $\begin{array}{l}\text { Prosentase } \\
(\%)\end{array}$ \\
\hline 1. & Belum & 3 & 2,9 \\
& Menikah & & \\
2. & Menikah & 93 & 90,3 \\
3. & Janda/Duda & 7 & 6,8 \\
\hline Jumlah & 103 & 100 \\
\hline \multicolumn{2}{l}{ Sumber: Data tahun 2016} \\
\hline
\end{tabular}

Tabel di atas menunjukan bahwa hampir seluruh responden berstatus menikah sebanyak 93 orang $(90,3 \%)$.

Tabel 5. Distribusi Frekuensi Responden Berdasarkan Tingkat Pendidikan

\begin{tabular}{llll}
\hline No. & $\begin{array}{l}\text { Tingkat } \\
\text { Pendidikan }\end{array}$ & (f) & $\begin{array}{l}\text { Prosentase } \\
(\%)\end{array}$ \\
\hline 1. & SD & 23 & 22,3 \\
2. & SMP & 28 & 27,2 \\
3. & SMA & 37 & 35,9 \\
4. & Perguruan & 15 & 14,6 \\
\multicolumn{2}{l}{ Tinggi } & & \\
\multicolumn{2}{l}{ Jumlah } & 103 & 100 \\
\multicolumn{2}{l}{ Sumber: Data tahun 2016}
\end{tabular}


Tabel di atas menunjukan bahwa hampir setengah responden memiliki tingkat pendidikan SMA sebanyak 37 orang $(35,9 \%)$.

Tabel 6. Distribusi Frekuensi Lama Menjalani Hemodialisis pada Pasien Gagal Ginjal Kronik

\begin{tabular}{llll}
\hline No & $\begin{array}{l}\text { Lama } \\
\text { HD }\end{array}$ & (f) & $\begin{array}{l}\text { Prosentase } \\
(\%)\end{array}$ \\
\hline 1. & $<6$ bulan & 16 & 15,5 \\
2. & $6-12$ bulan & 24 & 23,3 \\
3. & $>12$ bulan & 63 & 61,2 \\
\hline \multicolumn{2}{l}{ Jumlah } & 103 & 100 \\
\multicolumn{2}{l}{ Sumber: Data tahun 2016}
\end{tabular}

Tabel di atas menunjukan bahwa sebagian besar responden menjalani hemodialisis lebih dari 12 bulan sebanyak 63 orang $(61,2 \%)$.

Tabel 7. Distribusi Frekuensi Kualitas Hidup pada Pasien Gagal Ginjal Kronik

\begin{tabular}{llll}
\hline No. & $\begin{array}{l}\text { Status } \\
\text { Pernikahan }\end{array}$ & (f) & $\begin{array}{l}\text { Prosentase } \\
(\%)\end{array}$ \\
\hline 1. & Baik & 17 & 16,5 \\
2. & Cukup & 71 & 68,9 \\
3. & Kurang & 15 & 14,6 \\
\hline \multicolumn{2}{l}{ Jumlah } & 103 & 100 \\
\multicolumn{2}{l}{ Sumber: Data tahun2016 }
\end{tabular}

Tabel di atas menunjukan bahwa sebagian besar responden memiliki kualitas hidup yang cukup sebanyak 71 orang $(68,9 \%)$.

Tabel 8. Hubungan Antara Lama Menjalani Hemodialisis dengan Kualitas Hidup pada Pasien Gagal Ginjal Kronik di Ruang Hemodialisa RS Gatoel Mojokerto

\begin{tabular}{|c|c|c|c|c|c|c|c|c|}
\hline \multirow{4}{*}{$\begin{array}{l}\text { Lama } \\
\text { HD }\end{array}$} & \multicolumn{4}{|c|}{ Kualitas Hidup } & \multirow{3}{*}{\multicolumn{4}{|c|}{$\begin{array}{l}\text { Total } \\
\text { Kura } \\
\text { ng }\end{array}$}} \\
\hline & \multirow{2}{*}{\multicolumn{2}{|c|}{ Baik }} & \multicolumn{2}{|c|}{ Cukup } & & & & \\
\hline & & & & & & & & \\
\hline & $\mathrm{N}$ & $\%$ & $\mathrm{n}$ & $\%$ & $\mathrm{n}$ & $\%$ & $\mathrm{n}$ & $\%$ \\
\hline$<6$ bln & 0 & 0 & 10 & $\begin{array}{l}9, \\
7\end{array}$ & 6 & $\begin{array}{l}5, \\
8\end{array}$ & 16 & $\begin{array}{l}15 \\
.5\end{array}$ \\
\hline $6-12$ & 2 & 1, & 18 & 17 & 4 & 3 , & 24 & 23 \\
\hline bln & & 9 & &, 5 & & 9 & & ,3 \\
\hline$>12 \mathrm{bln}$ & 15 & 14 & 43 & 41 & 5 & 4, & 63 & 61 \\
\hline & & 6 & &, 7 & & 9 & &, 2 \\
\hline Jumlah & 17 & 16 & 71 & 68 & 1 & 14 & 10 & 10 \\
\hline & &, 5 & & ,9 & 5 & 6 & 3 & 0 \\
\hline
\end{tabular}

Tabel di atas menunjukan bahwa dari 103 responden dalam penilaian ini, sebagian besar responden 71 orang $(68,9 \%)$ memili kualitas hidup cukup yang sebagian besar responden menjalani hemodialisis lebih dari 12 bulan sebanyak 43 orang $(41,7 \%)$.

Hasil perhitungan data dengan menggunakan uji statistik Spearman rho, didapatkan $\mathrm{p}<\alpha$ yaitu $0,006<0,05$ dengan koefesien korelasi 0,267 . Sehingga $\mathrm{H}_{0}$ ditolak dan $\mathrm{H}_{1}$ diterima artinya bahwa ada hubungan sedang antara lama menjalani hemodialisis dengan kualitas hidup pasien gagal ginjal kronik di RS Gatoel Mojokerto.

\section{Pembahasan \\ Lama Menjalani Hemodialisis}

Tabel6 dapat diketahui bahwa sebagian besar responden menjalani hemodialisis lebih dari 12 bulan sebanyak 63 orang $(61,2 \%)$.

Lama hemodialisis merupakan jumlah waktu lama responden telah menjalani hemodialisis dalam bulan (Nurchayati, 2011). Hemodialisis adalah penggantian ginjal modern menggunakan dialisis untuk mengeluarkan zat terlarut yang tidak diinginkan melalui difusi dan ultrafiltrasi (O'callaghan, 2009). Bagi penderita gagal ginjal kronik, hemodialisis akan mencegah kematian karena terapi ini diperlukan untuk mempertahankan kelangsungan hidupnya dan mengendalikan gejala uremia, sehingga pasien dengan gagal ginjal kronik harus menjalani terapi dialisis sepanjang hidupnya yang berlangsung selama tiga kali seminggu 3-4 jam per kali terapi (Brunner \& Suddarth, 2002).

Hampir seluruh responden menjalani hemodialisis dengan rutin 1-2 kali seminggu selama 3-4 jam setiap kali hemodialisis. Hal ini disebabkan karena pasien gagal ginjal kronik yang memilih terapi hemodialisis harus menjalani terapi seumur hidup untuk menunjang kehidupanya. Dengan terapi hemodialisis kelebihan cairan dan sisa metabolisme yang tidak bisa dikeluarkan sendiri oleh pasien dapat dikeluarkan dengan alat pengganti ginjal. Alat pengganti ginjal ini bekerja secara ultrafiltrasi, difusi dan osmosis yang mampu menggatikan fungsi nefron pada ginjal, sehingga darah dapat disaring dengan proses ultrafiltrasi, sedangkan sisa metabolisme serta kelebihan cairan dapat dikeluarkan melalui proses difusi dan osmosis. 


\section{Kualitas Hidup Pasien Gagal Ginjal Kronik}

Tabel 7 dapat diketahui bahwa sebagian besar responden memiliki kualitas hidup yang cukup sebanyak 71 orang $(68,9 \%)$.

Kualitas hidup didefinisikan sebagai presepsi individu mengenai posisi mereka dalam kehidupan dalam konteks budaya dan sistem nilai dimana mereka hidup dan dalam kaitannya dengan tujuan, harapan standar dan perhatian mereka. Definisi ini mencerminkan pandangan bahwa kualitas hidup terfokus pada kualitas hidup yang "diterima" responden, definisi ini tidak diharapkan untuk menyediakan cara untuk mengukur gejala, penyakit atau kondisi dengan pola terperinci, melainkan efek dari penyakit dan intervensi kesehatan terhadap kualitas hidup (Nursalam, 2013). Faktor yang mempengaruhi kualitas hidup antara lain faktor sosial demografi seperti jenis kelamin, usia, pendidikan, status pernikahan dan pendidikan serta faktor lain seperti depresi, stage penyakit, lama hemodialisis, adekuasi hemodialisis dll (Maliani, 2014).

Berdasarkan teori di atas bahwa banyak faktor yang mempengaruhi kualitas hidup pada pasien gagal ginjal kronik. Faktor pertama yaitu jenis kelamin. Berdasarkan tabel 1 sebagian besar responden sebanyak 54 orang $(52,4 \%)$ berjenis kelamin laki-laki. Perempuan cenderung mempunyai kualitas hidup yang lebih rendah dibandingkan dengan laki-laki. Perempuan cenderung mudah stres dengan berbagai penyebab seperti ketidakstabilan hormon esterogen dan progresteron. Selain itu juga, penampilan merupakan hal yang sangat penting bagi perempuan pada umumnya. Namun, pada penderita gagal ginjal kronik terjadi perubahan fisik yang mengubah citra diri seseorang menjadi kurang menarik seperti warna kulit menjadi coklat keabu-abuan, kering dan gatal, rambut tipis mudah rontok dan patah serta berat badan bertambah akibat edema. Dengan perubahan fisik yang terjadi serta perempuan yang mudah stres yang akan mempengaruhi kualitas hidup pasien menjadi kurang baik.

Faktor kedua yang mempengaruhi kualitas hidup adalah tingkat pendidikan. Berdasarkan tabel 5 hampir setengah responden memiliki tingkat pendidikan SMA sebanyak 37 orang $(35,9 \%)$. Penderita yang memiliki pendidikan tinggi akan mempunyai pengetahuan yang lebih luas sehingga memungkinkan penguasaan diri dalam menghadapi masalah, mudah mengerti tentang apa yang dianjurkan oleh petugas kesehatan serta dapat mengurangi kecemasan sehingga dapat membantu individu tersebut dalam membuat keputusan (Dewi, 2015). Pasien dengan pendidikan tinggi memiliki pengetahuan luas yang dapat mempengaruhi sikap dan perilaku yang positif sehingga pasien bisa menerima kondisi yang dirasakanya. Penerimaan merupakan inti dari penilaian kualitas hidup, individu yang sudah menerima akan cenderung memiliki kualitas hidup yang baik.

Faktor ketiga yang mempengaruhi kualitas hidup adalah status pernikahan. Berdasarkan tabel 4 hampir seluruh responden berstatus menikah sebanyak 93 orang $(90,3 \%)$. Besar atau tidaknya dukungan yang diterima dari pasangan oleh penderita gagal ginjal kronik sangat menentukan perjalanan penyakit dan ketersediaan menjalani terapi. Dukungan dapat berupa motivasi, penghargaan, perhatian dan pemberian solusi (Putri, 2014). Dengan dukungan dari pasangan hidup, penderita gagal ginjal kronik dapat mengalami perubahan emosional seperti merasa diperhatikan serta lebih semangat untuk menjalani hidup. Perubahan emosional tersebut bisa merubah perjalanan penyakit ke arah yang lebih baik sehingga kualitas hidup pasien bisa menjadi lebih baik.

\section{Hubungan antara Lama Menjalani Hemodialisis dengan Kualitas Hidup Pasien Gagal Ginjal Kronik di RS Gatoel Mojokerto}

Hasil uji statistik Spearman rho, didapatkan $\mathrm{p}<\alpha$ yaitu $0,006<0,05$. Sehingga $\mathrm{H} 0$ ditolak dan $\mathrm{H} 1$ diterima artinya bahwa ada hubungan antara lama menjalani hemodialisis dengan kualitas hidup pasien gagal ginjal kronik di RS Gatoel Mojokerto.

Hal ini sesuai dengan teori Bestari (2015) bahwa lama menjalani hemodialisis mempengaruhi kualitas hidup pasien gagal ginjal kronik yang menjalani hemodialisis. Pasien yang menjalani hemodialisis lebih dari 12 bulan telah mencapai tahap longterm adaption (adaptasi lanjut) yaitu setelah satu tahun menjalani terapi HD, biasanya pasien 
sudah mulai terbiasa menerima keterbatasan dan komplikasi (Hawari, 2001; Arifin, 2010)

Lama menjalani terapi hemodialisis mempunyai pengaruh terhadap kualitas hidup. Setiap pasien memerlukan waktu yang berbeda-beda dalam beradaptasi terhadap perubahan yang dialaminya seperti gejala, komplikasi serta terapi yang dijalani seumur hidup. Sehingga kualitas hidup pada pasien gagal ginjal kronik juga mengalami fluktuasi sesuai dengan waktu yang diperlukan untuk setiap tahapan adaptasi terhadap terapi hemodialisis. Namun, sebagian besar responden yang menjalani hemodialisis lebih dari 12 bulan memiliki kualitas hidup yang cukup karena semakin lama pasien menjalani hemodialisis maka pasien akan terbiasa dan menerima segala gejala serta komplikasi. Pasien yang bisa menerima kondisinya dengan baik maka akan memiliki kualitas hidup yang baik pula, karena kualitas hidup terfokus pada penerimaan responden terhadap kondisi yang dirasakanya.

Tabel 8 dapat dilihat bahwa responden yang menjalani hemodialisis kurang dari 6 bulan memiliki kualitas hidup cukup sebanyak 10 orang $(9,7 \%)$ dan kualitas hidup kurang sebanyak 6 orang $(5,8 \%)$.

Menurut Hawari (2001) dalam Arifin (2010), pasien GGK yang menjalani terapi HD mengalami beberapa stadium adaptasi. Pada periode pertama yaitu periode honey moon (bulan madu) yang dimulai minggu pertama HD sampai 6 bulan, dimana pasien masih menerima ketergantungan mesin HD, masih punya rasa percaya diri dan penghargaan. Menurut Bestari (2015) kualitas hidup juga dipengaruhi oleh pengalaman, kepercayaan, harapan dan persepsi orang tersebut sehingga kualitas hidup ini lebih bersifat subjektif yang menilai posisi mereka dalam kehidupanya.

Menurut teori diatas pada periode honey moon, pasien yang masih bisa menerima ketergantungan mesin HD bisa memiliki kualitas hidup yang cukup bahkan baik. Karena kualitas hidup yang berfokus pada persepsi individu terhadap penerimaan kondisi dalam kehidupanya. Namun berbeda pada 6 orang $(5,8 \%)$ yang menjalani hemodialisis kurang dari 6 bulan memiliki kualitas hidup yang kurang. Dilihat dari 5 domain dari kualitas hidup, bahwa mayoritas 6 responden memiliki nilai domain fisik yang rendah sehnigga memiliki kualitas hidup yang kurang. Keadaan ini disebabkan karena salah satu dampak dari penyakit gagal ginjal kronik yaitu peubahan fisik responden. Perubahan fisik yang sering terjadi pada pasien gagal ginjal kronik anatara lain, lemas, mual, muntah, edema, sesak nafas, nyeri daerah ekstremitas, pusing dll. Sehingga kemampuan responden untuk beraktivitas menjadi terbatas.

Tabel 4 dapat dilihat bahwa responden yang menjalani hemodialisis 6-12 bulan memiliki kualitas hidup baik 2 orang $(1,9 \%)$, kualitas hidup cukup sebanyak 18 orang $(17,5 \%)$ dan kualitas hidup kurang sebanyak 4 orang $(3,9 \%)$.

Menurut Hawari (2001) dalam Arifin (2010), periode selanjutnya adalah periode disenchantment - discouragement (kecewakeputusasaan) yaitu setelah 6 bulan sampai 12 bulan menjalani terapi HD, hal ini ditandai dengan perubahan perilaku stres. Kualitas hidup yang baik dapat ditandai dengan bebas dari keluhan penyakit, fungsi tubuh yang normal, perasaan sehat dan bahagia, pekerjaan yang memuaskan, hubungan interpersonal yang baik dan kemampuan yang baik dalam menghadapi stres dalam kehidupanya (Bestari, 2015).

Teori diatas pada periode disenchantment - discouragement pasien memperlihatkan perubahan perilaku stres yang akan mempengaruhi kualitas hidup pasien menjadi kurang baik. Namun berbeda pada 2 orang $(1,9 \%)$ yang memiliki kualitas hidup baik dan 18 orang $(17,5 \%)$ yang memiliki kualitas hidup cukup. Dilihat dari faktor lain yang mempengaruhi kualitas hidup seperti status pernikahan dan dukungan sosial, bahwa mayoritas dari 2 orang dan 18 orang tersebut memiliki status menikah dan mendapatkan dukungan yang positif dari keluarga serta petugas kesehatan. Dengan banyaknya dukungan yang diberikan, pasien akan dapat menjalin hubungan interpersonal yang baik. Hubungan tersebut dapat mengurangi stres yang dirasakanya dengan cara menceritakan perasaan yang dirasakanya kepada orang terdekat. Selain itu juga, peran petugas kesehatan yang aktif sebagai konselor, edukator, advokator serta melakukan perawatan secara langsung dapat mencegah komplikasi dari penyakit sehingga mempengaruhi kualitas hidup responden menjadi lebih baik. 
Tabel 4 dapat dilihat bahwa responden yang menjalani hemodialisis lebih dari 12 bulan memiliki kualitas hidup baik sebanyak 15 orang $(14,6 \%)$, kualitas hidup cukup sebanyak 43 orang $(41,7 \%)$ dan kualitas hidup kurang sebanyak 5 orang $(4,9 \%)$.

Menurut Hawari (2001) dalam Arifin (2010), periode terakhir adalah periode longterm adaption (adaptasi lanjut) yaitu setelah satu tahun menjalani terapi HD, biasanya pasien sudah mulai terbiasa menerima keterbatasan dan komplikasi. Menurut Nursalam (2013) kualitas hidup didefinisikan sebagai persepsi individu mengenasi posisi mereka dalam kehidupan, karena kualitas hidup terfokus pada kualitas hidup yang diterima oleh individu.

Teori diatas pada periode longterm adaption, pasien cenderung memiliki kualitas hidup yang cukup sampai kualitas hidup yang baik, karena pasien mampu menerima keterbatasan akibat gejala serta komplikasi dari penyakit dan terapi hemodialisis. Namun berbeda pada 5 responden $(4,9 \%)$ yang menjalani hemodialisis lebih dari 12 bulan memiliki kualitas hidup yang kurang. Hal ini terjadi karena ada faktor lain yang mempengaruhi kualitas hidup seperti usia. Mayoritas dari 5 responden telah memasuki usia lansia awal, yang mana terjadi proses penurunan fungsi organ tubuh yang dapat memperburuk perjalanan penyakit dan komplikasi. Semakin banyak gejala dan komplikasi yang dirasakan responden maka akan semakin berkurang kualitas hidupnya.

\section{Simpulan}

Lama menjalani hemodialisis pada pasien gagal ginjal kronik di Ruang Hemodialisa RS Gatoel Mojokerto, sebagian besar responden menjalani hemodialisis lebih dari 12 bulan sebanyak 63 orang $(61,2 \%)$.

Kualitas hidup pada pasien gagal ginjal kronik di Ruang Hemodialisa RS Gatoel Mojokerto, sebagian besar responden memiliki kualitas hidup yang cukup sebanyak 71 orang $(68,9 \%)$.

Ada hubungan antara lama menjalani hemodialisis dengan kualitas hidup pasien gagal ginjal kronik di RS Gatoel Mojokerto sesuai dengan uji statistik spearman rho, didapatkan $\mathrm{p}<\alpha$ yaitu $0,006<0,05$.

\section{Saran}

Bagi Penderita Gagal Ginjal Kronik

Penderita gagal ginjal kronik diharapkan rutin menjalani terapi hemodialisis serta mematuhi larangan dan anjuran yang diberikan, dengan begitu diharapkan kualitas hidup penderita gagal ginjal kronik menjadi lebih baik.

\section{Bagi Perawat}

Berdasarkan hasil penelitian didapatkan bahwa sebagian besar responden memiliki kualitas hidup cukup, namun ada satu domain yang memiliki rata-rata rendah yaitu domain fisik. Sehingga diharapkan perawat menjaga adekuasi hemodialisis serta selalu mengingatkan pasien tentang diet yang diberikan, dengan begitu kadar BUN dan SC diharapkan stabil dan nilai domain fisik bisa meningkat.

\section{Bagi Peneliti Selanjutnya}

Diharapkan peneliti selanjutnya dapat melanjutkan penelitian dengan menambahakan kriteria inklusi dan ekslusi pada sampel yang bertujuan untuk mengontrol faktor lain yang mempengaruhi kualitas hidup serta memodifikasi kuesioner KDQoL 36 sesuai dengan kondisi di tempat penelitian.

Diharapkan peneliti selanjutnya juga dapat melanjutkan penelitian dengan tujuan untuk meneliti faktor lain yang mempengaruhi kualitas hidup penderita gagal ginjal kronik seperti depresi, dukungan sosial, adekuasi hemodialisis dan interdialityc weight gain (IDWG).

\section{Daftar Pustaka}

Arifin,N.(2010). Analisis Faktor-Faktor yang Berhubungan dengan Tingkat Kecemasan Pasien Gagal Ginjal Terminal Selama Menjalani Terapi Hemodialisis di Badan Pelayanan Kesehatan RSU Tidar Kota Magelang. Diambil dari JTPTUNISMU http://digilib.unimus.ac.id

Arikunto, S. (2013). Prosedur Penelitian. Jakarta : Reneka Cipta.

Baradero, M., Dayrit, M. W., \& Siswadi, Y. (2009). Klien Gangguan Ginjal: Seri Asuhan Keperawatan. Jakarta: EGC. 
Brunner \& Suddarth. (2002). Buku Ajar Keperawatan Medikal Bedah Edisi 8 Volume 2. Jakarta: EGC

Bestari, A.W. (2015). Faktor yang berhubungan dengan Kualitas Hidup Pasien Gagal Ginjal Kronik yang menjalani Heodialisis. Diambil dari adln.lib.unair.ac.id /gdlhub-gdl-sl2015-bestariani-41071-7.pdf

Dewi, S. P. (2015). Hubungan Lamanya Hemodialisis dengan Kualitas Hidup Pasien Gagal Ginjal di RS PKU Muhammadiyah Yogyakarta. Diambil dari http://opac.say.ac.id/id/eprint/234

Farida, A. (2010). Pengalaman Klien Hemodialisis Terhadap Kualitas Hidup Dalam Konteks Asuhan Keperawatan di RSUP Fatmawati Jakarta. Diambil dari lib.ui.ac.id/file?file=digital/137288T-Anna\%20Farida.pdf

Chang, E, dkk. (2010). Patofisiologi Aplikasi pada Praktik Keperawatan. Jakarta: EGC

Harrison. (2013). Nefrologi dan Gangguan Asam-Basa. Jakarta: EGC. .(2013). Buku Saku Nefrologi Disertai Contoh Kasus. Tangerang: KARISMA.

Hastono, S.P. \& Sabri, L. (2010). Statistika Kesehatan. Jakarta: Rajawali Pers

Hays R.D., Kallich J. D., Mapes D. L., Coons S. J., Carter W. B. (1994). Development of the kidney disease quality of life (KDQOL) instrument. Qual Life Res 1994, Oct;3(5):329-38

Hidayat, A. A. A. (2008). Metode Penelitian Keperawatan dan Teknik Analisa Data.Jakarta : Salemba Medika.

Kendall, K., \& Tao, L. (2013). Sinopsis Organ System Ginjal Pendekatan dengan Sistem Terpadu danDisertai Kumpulan Kasus Klinik. Tangerang: Karisma Publishing Group.

LPPM. (2015). Buku Panduan Penyusunan Skripisi. Mojokerto: STIKes Bina Sehat PPNI Mojokerto

Mahdiana, R. (2010). Mencegah Penyakit Kronis Sejak Dini. Yogyakarta: Tora Book

Mailani, F. (2015). Kualitas Hidup Pasien Penyakit Ginjal Kronik yang Menjalani Hemodialisis: Systematic
Review. Ners Jurnal Keperawatan , 1-8.

Muhammad, A. (2012). Serba Serbi Gagal Ginjal. Jogjakarta: DIVA Press.KARISMA Publishing Group.

Notoatmodjo, S. (2012). Metode Penelitian Kesehatan. Jakarta: Rineka Cipta.

Nurarif, A. H., \& Kusuma, H. (2015). Aplikasi Asuhan Keperawatan Berdasarkan Diagnosa Medis \& NANDA NIC-NOC. Jogjakarta: MediAction publishing.

Nurchayati, S. (2011). Analisis FaktorFaktor yang Berhubungan dengan Kualitas Hidup Pasien Penyakit Ginjal Kronik yang Menjalani Hemodialisis di Rumah Sakit Islam Fatimah Cilacap dan Rumah Sakit Umum Daerah Banyumas. Diambil dari lontar.ui.ac.id

Nursalam. (2013). Metode Penelitian Ilmu Kesehatan. Jakarta : Salemba Medika.

O'Callaghan, C. (2009). At a Glance Sistem Ginjal Edisi ke Dua. Jakarta: Erlangga.

Putri, R. (2014). Gambaran Kualitas Hidup Pasien Gagal Ginjal Kronik yang Menjalani Terapi Continuous Ambulatory Peritoneal Dialysis di RSUD Arifin Achmad Provinsi Riau dengan Menggunakan Kuesioner KDQOL-SF.

Riwidikdo, H. (2009). Statistik Kesehatan Belajar Mudah Teknik Analisa Data dalam Penelitian Kesehatan (Plus Aplikasi Software SPSS). Jogjakarta: Mitra Cendikia Press.

Rachmawati, S. (2013). Kualitas Hidup Orang Dengan Hiv/Aids Yang Mengikuti Terapi Antiretroviral. Jurnal SAINS Dan Praktik Psikologi , 50 .

Schatell, D., \& Witten, B. (2012). Measuring Dialysis Patient's Health-Related Quality of Life with KDQOL-36 ${ }^{T M}$. Medical Education Institute

Setiadi. (2013). Konsep dan Praktik Penulisan Riset Keperawatan Edisi 2. Yogyakarta: Graha Ilmu.

Sugiyono. (2013). Metode Penelitian Pendidikan. Bandung: Alfabeta.

Supriyadi, dkk. (2011). Tingkat Kualitas Hidup Gagal Ginjal Kronik Terapi 
Hemodialisa. Jurnal Kesehatan Masyarakat, 107-112.

Thaweethamcharoen et al. (2013). PatientReported Outcomes (Pro) Or Quality Of Life (Qol) Studies Validity And Reliability of Kdqol-36 In Thai Kidney Disease Patient. Value in health regional issue 3: 98-102 